\title{
PUBLIC SECTOR FINANCIAL REFORMS: WHICH CONVERGENCE BETWEEN EUROPEAN MEMBER STATES?
}

\author{
Michaela SOVERCHIA ${ }^{1}$ \\ University of Macerata, Italy
}

\begin{abstract}
Recently, many countries have undertaken government accounting and financial reporting reforms, at central and local level, in order to meet transparency, accountability and comparison needs. In the meantime, the International Public Sector Accounting Standards Board issued the first set of accounting standards specifically dedicated to public sector; but their adoption is not compulsory, so not all countries referred to them in reforming their government financial reporting. Given that a standardised government accounting and financial reporting model does not exist, this study compares three European countries (France, Italy and the United Kingdom) and one supranational institution (European Union) in order to highlight similarities and differences between accounting reforms recently carried out at central level. The aim of the paper is to verify if a set of common elements can be identified, as to consider them a first step towards European central government financial reporting harmonization.
\end{abstract}

8- Public sector accounting, accrual accounting, central government financial reporting, Europe

${ }^{1}$ Correspondence address: Michela Soverchia, Department of Economic and Finance Sciences, University of Macerata, Via Crescimbeni, 20 - 62100 Macerata, ITALY, Phone: +39.0733.2583241, Fax: +39.0733.2583205, E-mail: so verchia@unimc.it. 
Public sector financial reforms: which convergence between European member states?

\section{INTRODUCTION}

Last decades have been characterized by deep transformations which involved the world of public administrations (PAs) in a transversal way, determining relevant changes in their working models and in the role played within the society. It is a question of rationalization and modernization, still on going in many contexts, referred to many dimensions of PAs, started and spread with different peculiarities and timing, in the developed world as well as in transition countries.

Different kinds of PAs have been involved (local, national, supranational and international), as well as various areas of public intervention and public services (health, education, social services and so on).

These processes have taken place from a condition of more or less deep crisis that involved public sector. Generally, the qualitative and quantitative evolution of the public intervention in the society implied a substantial increase of public expenditures, without a corresponding, effective increase of benefits; this problem caused deeper and deeper imbalance situations between imposed sacrifices for taxpayers and delivered public services. With reference to Europe, being a European Union (EU) member States - and so having the obligation to respect EU economic and financial standards - constituted an important stimulus for public sector reforms' realization.

Such phenomenon, together with a lot of specific causes inherent to single contexts, determined the urgent need of a recovery of efficiency and effectiveness of the action of PAs that is the ability to realize their institutional aims in sustainable financial and economic conditions. In the actual social and economic background, this element is an essential factor as for countries' international competitiveness, thanks to important functions carried out by PAs in services' production and delivery, that influence and support enterprises' development and competitiveness.

These reforms, differently developed in various public fields, have been worked out under the New Public Management (NPM) paradigm (Aucoin, 1990; Hood, 1991, 1995; Barzelay, 2001; Gruening, 2001; Pollit \& Bouckaert, 2004; Pollit et al., 2007). It analyses different processes of rationalization and change in the working of PAs from an organizational, managerial and financial point of view, focusing on the best technical-productive solution's search through the use of practises like performance measurement, performance budgeting, management by objectives, that are typical business principles and instruments adapted to public sector.

Literature and studies referred to the NPM are huge, so it is difficult to give an exact and shared definition of it, especially because we are talking about something 
that is still in evolution. For example, Ferlie et al. (1996) consider NPM like a different models sequence stratified in time: the efficiency drive model, the downsizing and decentralization model, the search of excellence model and the public service orientation model.

As Kettl (2005) pointed out, there is a quite defined common strategy for public management reforms realized all over the world, that is "the global public management revolution", because most of reform processes have been based on similar theoretical and conceptual approaches, modified and adjusted according to specific organizational and cultural contexts: referring to NPM, the expression "umbrella term" is often used (Anessi Pessina, 2007: 9).

Several theoretical and empirical studies show that different strategies are used to achieve public management reforms (Jones et al., 2004):

$>$ increased accountability;

$>$ decentralization and delegation of authority and responsibility for decision making and management;

$>$ application of information technology to improve governments' management and responsiveness towards citizens;

$>$ developing and improving management control systems;

$>$ introduction of measures to reduce corruption in government, business and society;

$>$ development and use of performance indicators;

$>$ integration of performance measurement and management.

Within these processes, public sector accounting systems reforms also take place: it is the New Public Financial Management (NPFM) (Olson et al., 1998), which shows an increasing importance of financial and accounting dimension of public sector management reforms. All fields of public sector accounting have been involved: management accounting, financial accounting and auditing (Jones \& Pendlebury, 2000). In this area, changes in financial reporting systems are considered one of the "key elements of financial reforms" (Olson et al., 1998). In fact, financial resources are an essential condition for PAs' working and survival, thus the control of the use-ways of these resources is an endless discussion topic for academics and professionals.

The aim of this study is firstly to study and deepen the accounting and financial reporting reforms carried out by the selected PAs (three central governments, that are France, Italy and the United Kingdom, and one supranational PA, that is European Union); secondly, to compare their main features, verifying similarities and differences in order to understand if a set of common elements can be identified, as to talk about a significant convergence between the analyzed reforms. 


\section{Public sector financial reforms: which convergence between European member states?}

After this introduction to the research context, the paper is structured as follows: next section sets a theoretical framework, providing a brief overview of literature and previous research referred to the research topic; the third section is dedicated to clarify the research design and method; the forth section sums up the analysis of the selected case-study; finally, a discussion on findings and research results with concluding remarks will be presented.

\section{THEORETICAL BACKGROUND}

As mentioned above, reform processes related to public sector financial and accounting models are generally identified in literature as NPFM' s experiences.

In short, some of the main changing lines characterizing them are (Olson et al., 1998; Guthrie et al., 1999):

- growing interest in financial reporting - moving from cash basis accounting to accrual basis accounting - and issuing of accounting standards for public sector;

- innovation in budget models, inspired to performance budgeting;

- decentralization of economic responsibilities;

- changing in internal and external au diting systems;

- introduction of private sector management techniques, as well as development of assessing performance measurement in order to monitor the efficiency and effectiveness degree with which public services are delivered, evaluating the financial consequences of management decisions;

- externalization of activities and services which do not belong to the core of PAs;

- use of financial and performance measures to assess outputs and outcomes arising from different public sector activities;

- performance auditing and evaluation processes.

However, the NPFM reform processes carried out all over the world are characterized by similarities but also differences: national governmental accounting systems' stage of development varies greatly (Caperchione, 1999; Lüder \& Jones, 2003).

Accrual-based accounting systems introduction is one of the most significant lines of recent public sector accounting reforms.

However, this is not a new subject. Several attempts on commercial accounting introduction in public sector have been made: for instance, the ones carried out in Spain in the XVI century (Jurado-Sanchez, 2002), in the UK and Italy in the XIX century (Edwards et al., 2002; Anselmi, 2006), in the USA in the first part of the XX century (Antony, 2000). Reasons for which these attempts did not succeed are different and they vary according to the specific countries' context: the common 
element seems to concern low compliance with public sector needs and features (Anessi Pessina, 2007:26).

As for advantages issuing from accrual accounting application in public sector, many studies have been conducted (Pallot, 1997; Brorström, 1998; Guthrie, 1998; Perrin, 1998; Yamamoto, 1999; Chan, 2003; IFAC-PSC, 2003 b; van der Hoek, 2005; FEE, 2007). According to this wide literature, main positive aspects are:

- link with management accounting;

- costs measurement of supplied services and political programmes, so as to maximize PAs' efficiency and productivity;

- monitoring of assets;

- more accurate measurement and communication of public sector entities' financial position and performance;

- long term assessment of public policies financial sustainability;

- possibility to draw up consolidated financial statement;

- internal use of this added information (prices statement, make or buy choices, outsourcing, etc.);

- external use of this added information: improve PAs' transparency, accountability and performances evaluation for stakeholders' benefit.

These advantages correspond more or less directly to cash accounting lacks: it does not allow carrying out the above mentioned measu res and assessments; consequently, it does not fit into public resources management control, being not able to highlight the connection between resources consumption and achieved results.

There are also theoretical and empirical studies that point out problems arising from accrual accounting implementation in public sector.

From a theoretical point of view, some authors argue that cash accounting is more suitable for PAs' kind of activities, sometimes consisting of merely fund transfers. Other authors claim that, if PAs' last aim does not fit with profit, financial performance cannot be a relevant measure. Finally, some studies underline that a conceptual pattern has not been identified and followed while putting in practice accrual accounting reforms, resulting into an uncritical transferring of business practices in PAs (Brorström, 1998; Guthrie, 1998; Ellwood, 2003; Christiaens \& Rommel, 2008): "there is a danger in adopting an uncritical assumption that private sector methods are superior to those of the public sector and should provide the model to be followed" (Hodges \& Mellet, 2003: 110).

Moreover, some operational difficulties have come out in implementing accrual accounting, deriving from the PAs' peculiar nature and kind of activities (Guthrie, 1998; Antony, 2000; Blöndal, 2002; Hodges \& Mellet, 2003; Steccolini, 2004a), such as:

drawing up the opening balance sheet, identifying and evaluating assets and liabilities at the starting point of the accounting reform; 


\section{Public sector financial reforms: which convergence between European member states?}

$>$ difficulties of accounting office staff in recording transactions under a double-entry bookkeeping system and managers' troubles in understanding accrual based financial reporting;

$>$ problems due to information systems solutions, concerning moving to the new accounting system, as well as transition project costs in relation to time, financial and human resources;

$>$ various problems due to single accounting items (for instance depreciations).

In fact, there are also some critical studies about NPFM reforms: they underline business-like accounting systems' limits concerning peculiar features of PAs, which realize extremely heterogeneous activities and produce many results that cannot always be measured and represented under a financial point of view (Mussari, 1999). "A range of measures is needed to cope with the multidimensional nature of public service" (Stewart \& Walsh, 1994: 46).

Some authors talk about an evaluatory trap, concerning the risk in developing accounting and performance measurement models more and more advanced, elaborated and expensive, undervaluing financial measuring difficulties of the PAs' results and considering measuring activity as an aim and not as a mean (Jones et al., 2001). "Faced with rising costs of monitoring and evaluation, more frequent and visible service charges and a growing loss of identity, the public service arena looks to be set on a spiral of decline, delivering fewer and fewer services. It is effectively cau ght in an evaluatory trap" (Olson et al., 2001:515).

In the area of public management reforms literature, studies that deepen these topics in a comparative way are numerous, developing proper models of analysis (Barzelay, 2001; Pollit \& Bouckaert, 2004).

Referring to comparative international public sector accounting, first works appeared from the end of the ' $80 \mathrm{~s}$ of the previous century, fed by public accounting reforms' progressive diffusion, in order to promote mutual comprehension among different national systems (Chan \& Jones, 1988). A significant propulsion to this research field was given by the Conting ency Model, created by professor Klaus Lüder (Lüder, 1992 and 1994), subsequently improved in the Financial Management Reform Process Model (Lüder, 2002). This model is a framework for empirical investigations concerning public sector accounting reforms, whose aim is to facilitate comparison and to explain contextual, behavioural and environmental factors' influence on accounting innovation processes. Several scholars used and applied it studying different countries' financial and accounting reforms (Chan, 1994; Mussari, 1995; Lapsley \& Pallot, 2000; Vela \& Fuertes, 2000; Lüder \& Jones, 2003). 


\section{RESEARCH DESIGN: GOAL, QUESTIONS AND METHODOLOGY}

In this paper the attention is focused on the European continent: as explained in the introduction, the main purpose of this study is to deepen central government accounting and financial reporting reforms recently carried out by some selected European countries, in order to emphasize similarities and differences and to understand if some common elements exist, so much to outline a significant convergence between the analyzed reforms.

Therefore, within the wide reform processes that involved the accounting models of these PAs, in a broad and extensive way, we only focused our attention on the accounting system and financial reporting, whereas other aspects (such as budgeting, auditing, management control) haven't been considered: the intention with this paper was not to provide detailed coverage of all the accounting solutions developed by the analysed PAs, but rather to underline the main changing elements introduced to face the challenge of the accounting model modernization.

From the above mentioned research goal, the following set of research questions has been derived:

$\checkmark$ are these accounting reforms coherent to international trends?

$\checkmark$ is there a convergence between the selected cases' accounting models?

$\checkmark$ is it possible to point out an influence of EU on the accounting reforms carried out by the analyzed European member States?

$\checkmark$ what is the role played by the accounting standards, in particular by IPSAS (International Public Sector Accounting Standards), the only set of accounting standards for public sector issued by an international body?

To answer to these questions, three countries, all EU member States (France, Italy and the UK), and one supranational institution, that is European Union, have been analysed.

Why those countries? As for selecting and screening cases (Patton, 2002), the starting point was the analysis of the Italian central government case; so, the choice has been made both on a similar country (France) and on a different one (UK) with reference to administrative culture, political and institutional system, as well as for accounting culture (Jones, 2007: 91). Finally, giving the research goal, we focused on the EU case: in fact European countries are autonomous as for their own government accounting model, but they are members of a supranational organization - EU - that perhaps will become more and more stronger; for this reason we think that it is very important to monitor what is going on with the EU accounting reform. 


\section{Public sector financial reforms: which convergence between European member states?}

In the following analysis, some context aspects have been also considered, because of their contribution in outlining the political, institutional and administrative framework in which these reforms developed (Lüder, 2002; Pollit-Bouckaert, 2004).

The employed method, coherently with the descriptive and explorative research aims, is the multiple cases study (Eisanhardt, 1989; Yin, 2003; Fattore, 2005). In fact, as Berry and Otley (2004: 231) argue, case based research can provide a rich understanding in the content, process and context of an empirical phenomenon.

In order to compare those cases, their analysis has been carried out in a homogeneous way, taking into consideration the following elements:

- some institutional and administrative systems features;

- the processes of the accounting reforms: timing, used tools, involved actors, main goal and contents;

- the basis of the accounting systems;

- the accounting principles and standards;

- the financial reporting, with particular focus on financial statements.

This is a documental analysis: in addition to literature review, the empirical material used concern government financial statements, accounting rules and regulation, accounting standards, accounting manuals and other work documents produced by government offices sii $^{\text {. }}$

\section{CASE-STUDY ANALYSIS}

\subsection{France}

France is a semi-presidential republic with legalistic state traditions (Pollit \& Bouckaert, 2004: 247-255). It is a country characterized by historical tradition of strong centralization of decision-making and administrative management (Rechtsstaat administrative culture), that have been particularly strengthened during the Napoleonic period. Since the early ' 80 s of the previous century, however, a process introducing elements of administrative decentralization through powers and functions division between central and local PAs - Regions, Departments and Municipalities - has begun (Cole \& Jones, 2005; Kickert, 2005). This process, which continues in the ' 90 s, reaches its peak with the approval of the Constitutional Law of $28^{\text {th }}$ March 2003, defining France a decentralized republic and introducing the principles of subsidiarity and financial autonomy.

French government accounting system modernization was made official with the constitutional bylaw on budget acts of $1^{\text {st }}$ Au gust 2001 (loi organique relative aux loi de finances - LOLF), that replaced the previous accounting rules, the ordonnance organique n. 2/1959. 
LOLF introduced some important and relevant changes, predicting a progressive application that was fully implemented in 2006, regarding both budget and financial reporting. The reform movement, however, has earlier roots: a crucial step was the accrual accounting taskforce report submitted in 1999 to the Ministry of Finance (IFAC-PSC, 2003 a).

With reference to this research topics, this reform process is in line with international trends: in fact, the goal to introduce an accrual based financial reporting was set, with the objective to make financial information more transparent, so as to provide Parliament and all central government's stakeholders better information about public resources consumption (Chevauchez, 2002: 285304). In 2006, after building the opening balance sheet, financial statements were prepared for the first time according to current rules.

One of the reform's distinctive features is the so-called dual system: while the cash basis accounting system realized with single-entry bookkeeping has been kept for budget appropriations management (the budget has legal authorization value), an accrual accounting system has been introduced, in order to provide information about the State financial position and performance. "The general public accounting system is based on the accrual basis principle [...]. The rules applicable to government accounting only differ from those applicable to companies in terms of the specific nature of government action" (LOLF, art. 30).

Facts and transactions are recorded only once in the budgetary accounting system, but thanks to the existence of a correspondence between the two charts of accounts (the budgetary one and the financial reporting one), these entries also feed the accrual based accounting system. Thus, financial accounting information availability is due to data-processing carried out at central level at the end of the financial year, based on peripheral budgetary bookkeeping (Mussari, 2005b: 31).

French accounting culture is greatly influenced by the accounting standardization experience begun in the "40s of the last century (Standish, 1990). Until now, rules set that all companies and public entities arrange their accounting system based on the French Chart of Accounts (Plan Comptable Général) that is adapted to specific features and information needs of different kind of organizations to which it refers from time to time. For PAs this adjustments take place with government regulations: for example M21 for hospitals and other health public bodies and M14 for Municipalities (IFAC-PSC, 2003a).

Accounting principles and standards are set by the State: the article 30 of the LOLF provides the establishment of a Committee for Public Accounting Standards, appointed in 2002 and located nearby the Minister of Budget. The standards committee has the mission to formulate some advice on exposure drafts submitted by the Minister of Budget offices ${ }^{\text {iii }}$. 


\section{Public sector financial reforms: which convergence between European member states?}

This committee approved fifteen Central Government Accounting Standards up to now, issued by the French Ministry of Economy (Ministère de l'Economie, des Finances et de l'Industrie, 2008). In addition, also a Conceptual Framework for Central Government Accounting was issued, designed with special reference to the French Chart of Accounts, IPSAS and IASB's standards, even if some original solutions may be required because of French central government specific features; anyway, they must be justified and consistent with the conceptual framework.

The fifteen central government accounting standards have a homogeneous structure that includes:

- an introduction, that explains the standard, any specific features of the central government in the area under consideration, the accounting choices and how the standard compares to other standard benchmarks (IPSAS, IAS/IFRS);

- the standard body with a four-parts structure: scope, accounting treatment, valuation and disclosures in the notes;

- some examples illustrating how the standard fits into the legal and financial context.

As stated from the accounting standard 1, the French central government general accounts are composed of several documents, according to the international business practice.

First of all the statement of financial position, presented as a list. It shows all assets, which are a list of balance sheet items with a positive economic value for the central government (fixed assets, current assets, accruals and deferred revenues for the financial year), and liabilities, which are obligations towards other entities recognised on the reporting date (they include provisions for risks and liabilities, financial debts, non-financial debts, other liabilities, accruals and deferred expenses for the financial year). In addition, the statement of financial position shows separate cash items on both the assets and liabilities sides and a financial position item also ${ }^{\text {iv }}$.

Then, the surplus/deficit statement, which includes all expenses and revenues of the year, is broken up into three parts:

- the net expenses statement, that breaks down expenses on the basis of their nature, showing the total amount of net expenses that is not covered by revenues from corresponding activities;

- the net sovereign revenues statement, structured in categories (taxes and other sovereign revenues), showing the revenues arising from the exercise of central government's powers, with no direct equivalent exchange for other parties;

- the net operating surplus/deficit statement for the period, which shows the difference between net expenses and net sovereign revenues arising from the two above mentioned parts of the document. 
This statement's structure really points out one of the most important managerial peculiarities of PAs. Expenses and revenues are not connected, unlike what happens in profit-oriented companies: resources consumption related to delivered services has not a corresponding amount due, since public revenues have mostly a tax nature, especially in central governments.

The cash flow statement presents inflows and outflows relating to assets and liabilities of the year and classifies them by categories:

$>$ cash flows from operating activities, which correspond to receipts and payments linked to transactions and interventions (except for investments) and other receipts and payments that can be linked to operating activity, such as cash flows corresponding to financial expenses and revenues;

$>$ cash flows from investment transactions, which correspond to receipts and payments stemming from fixed assets acquisition and disposal;

$>$ cash flows from financing transactions, which correspond to receipts and payments regarding central government's external financing transactions.

The notes provide all information needed in understanding and interpreting main financial statements' items. Furthermore, because of the dual system, notes include transition tables to identify differences between cash-based budget accounts and accrual-based financial statements.

\subsection{Italy}

Italy is a parliamentary republic with a civil law legal system (Pollit \& Bouckaert, 2004: 264-269).

In recent years some legislative reforms have been realized - inspired by the subsidiarity principle - in order to obtain a relevant administrative decentralization, carried out with functions and powers' transfer from central government to regions and local authorities (Longo, 2001; Mussari, 2005a). This process had its peak with the approval of the Constitutional Law n. 3/2001 - that has to be fully implemented yet - with which the State recognized to local governments a high degree of institutional, organizational, managerial and financial autonomy.

The accounting reform process recently undertaken by the Italian central government has predominantly focused on budget, and - as a civil law country - it has taken place by law.

With regard to the accounting system, Italy has made a choice that seems to depart from international trends. The reform started in 1997 maintained cash accounting (full and modified). Without introducing accrual based financial accounting, a cost 


\section{Public sector financial reforms: which convergence between European member states?}

accounting system has been created, based on cost measurements to be referred to cost centres, in order to obtain information about public resources employ by different organizational units and, furthermore, to use this information to support budgeting process (Pavan \& Reginato, 2005).

This accounting system, which became operative in financial year 2000, is based on:

$\Rightarrow$ a chart of accounts;

$\Rightarrow$ a chart of cost centres, arising from responsibility centres in which each organizational unit is divided, coherently to the bu dget stru cture;

$\Rightarrow$ a chart of delivered services;

$\Rightarrow$ a manual of accounting principles and rules, providing operational instructions (Ragioneria Generale dello Stato, 2008).

This cost accounting system is designed to support the drafting of an accrual budget structured in cost centres, derived from the legal cash-based budget. It contains the objectives to be achieved in terms of functions to be performed and services and activities to be carried out, by allocating human, financial and instrumental resources and targets to managers responsible for the different organizational units.

Cost accounting recording is made on a six-monthly base, according to the accrual accounting principle "that takes as reference the cost, that is actual consumption of resources - goods and services - rather than charges, which represent cash disbursement related to their acquisition" (Ragioneria Generale dello Stato, 2008: 7). These costs do not arise from financial accounting system based on double-entry bookkeeping, but are derived from cash-based single-entry bookkeeping, with extraaccounting system adjustments, and they are not used to draw up financial statements.

Given that Italian government does not have an accrual based financial accounting system, it did not issue accounting standards related to financial reporting.

The Italian annual report is made up of two main statements: in addition to the budget account, based on cash and modified cash accounting (mirror image of the budget), the balance sheet is also drawn up. It gives information about the State financial position resulting at the end of the year, highlighting changes in capital assets and equity, even if they do not come from financial accounting, as above explicated.

This statement shows government assets and liabilities: the structure, provided by law (D. Lgs. 279/1997 and Decreto Interministeriale $18^{\text {th }}$ April 2002) and divided into classes, includes financial and non-financial assets and liabilities. 
Then, annual report includes transition tables to clarify the link between cash accounting results and the final balance sheet, and, since 2007, the correspondence between cash accounting and cost accounting, showing integrative and rectification items, as stated by D. Lgs. 279/1997, art. 11 .

In spite of made efforts, Italian assets and liabilities measurement and disclosure seem to be not sufficient yet: beyond problems regarding valuation rules and financial representation requirements for all public sector entities (for instance about capital assets), the main negative element is that figures shown in the balance sheet do not derive from a systematic bookkeeping, but from inventory recording. This fact causes doubts about the figures' reliability and it forces, sometimes, to extreme simplification: think about depreciations, introduced only from 2000 onwards.

\subsection{United King dom}

The UK is a constitutional monarchy with an unwritten constitution: unlike the two above mentioned countries, its common law legal system is based on a small number of formally codified rules, which ensures to the UK a political and administrative system with a relevant flexibility degree. Its administrative culture is oriented to public service (Jones \& Pendlebury, 1988: 52-78; Pollit \& Bouckaert, 2004: 292-299).

The Anglo-Saxon budgeting and accounting system reform has to be considered as part of a broader administrative reform beginning in the ' 80 s of the last century under the Thatcher government. It was among the first in Europe that realized public management reforms introducing NPM principles and tools, carrying out a real turning point into the lines of economic policy with privatization and public expenditures reduction programs (Barzelay, 2001: 24-31; Chow et al., 2005).

For a long time the UK government accounting model was also based on cash accounting. However, this kind of accounting system's limits led government to start a radical reform of the budgeting and accounting system, characterized by the accrual accounting introduction on both sides (budgeting and reporting). This process followed other similar actions that, starting from the ' $80 \mathrm{~s}$, involved other parts of the UK public sector, particularly local authorities and health organizations.

The proposal was launched in 1993: after the issued analysis documents in which government highlighted the benefits of applying the new accounting system, the Resource Accounting and Budgeting reform (RAB) started to be implemented in 2000 , with the drawing up of the first accrual based accounting documents. However, it is with the 2001-2002 financial period that RAB became full working: for the first time government obtained parliament authorization with regard to 


\section{Public sector financial reforms: which convergence between European member states?}

resources to consume (costs), as well as cash need to face different public policies and objectives (Her Majesty's Treasury, 2001; Heald, 2005).

Transition from a full cash based system to an accrual based one was carried out through several stages (Likierman et al., 1995; Perrin, 1998). RAB model is not only based on accrual accounting principles, but it produces full information to investigate the link between resources consumption and results achieved by different government departments, with the aim to improve quality and quantity of delivered public services ${ }^{v}$. Therefore, it is not so much a matter of government budget and financial reporting reviewing, as the introduction of a financial system - in its broad and extensive way - "bringing to gether central government planning, budgeting, estimates and reporting on to a resource basis" (Her Majesty's Treasury, 2001:2).

In order to understand its most important features, the Government Financial Reporting Manual (FRM) is a particularly useful tool: this document is updated every year and it contains references and instructions referred to accounting principles and standards on which government financial reporting is based ${ }^{\mathrm{vi}}$.

Accrual accounting application is realized respecting the generally accepted accounting practice (GAAP), to the extent that it is meaningful and appropriate in public sector context. As stated by the FRM 2009-2010 ${ }^{\text {vil }}$, par 2.1.1, GAAP is composed of:

a) the accounting and disclosure requirements of the Companies Act 2006;

b) all IASB pronouncements (Framework for the Preparation and Presentation of Financial Statements, IAS/IFRS and SIC/IFRIC);

c) for charities registered in the UK, regulations issued under charities legislation and, where applicable, the Statement of Recommended Practice (SORP) Accounting by Charities issued by the Charity Commission;

d) the body of accumulated knowledge built up over time and promulgated for example in textbooks, technical journals and research papers.

Therefore, the UK government accounting model, as an accrual based system, does not apply IPSAS ${ }^{\text {viii }}$. With the 2009/2010 FRM version, the convergence project to IAS/IFRS has been realized: while the previous manual version put all documents issued by the Accounting Standards Board among GAAP (in particular the financial reporting standards - FRS, and the statements of standard accounting practice - SSAP), the current version only refers to the IASB's pronouncements. According to IFRS 1 content, the transition date to IAS/IFRS is $1^{\text {st }}$ April 2008 for the purposes of preparing the opening IFRS statement of financial position.

Referring to general accounting assumptions, the manual points out that financial statement must give a true and fair view. Other accounting principles are not listed, because the FRM directly refers to the IASB's Framework, providing 
interpretations and integrations with particular reference to specific features of the UK government's activities ${ }^{\text {ix }}$.

As far as financial reporting is concerned, the UK government bodies have to produce annual accounts according to chapter 5 of Government FRM 2009-2010.

Costs of the financial period incurred by each department and corresponding revenues are shown in the operating cost statement. The present document's structure establishes the division between administration costs and program costs, indicated separately by single request for resources (units on which the Parliament votes).

The statement of financial position, made as a list, shows first of all total assets, divided into current and non current assets; then liabilities (current and non current) are listed and lastly, as an algebraic sum, the taxpayers' equity, for which there is a specific document, the statement of changes in equity, with the aim to highlight changes occurred during the financial period ${ }^{\mathrm{x}}$.

The statement of cash flows, as stated in IAS 7, has the objective to provide information about the historical change in cash and cash equivalents of an entity, classifying cash flows during the period of operating, investing and financing activities.

Finally, with the notes, entities present a summary of accounting policies disclosing the measurement basis used in preparing financial statements, and all other relevant accounting policies to understand them.

An entire chapter of the Government FRM is dedicated to the whole of government accounts, for the whole UK public sector (central government, local government and public corporations), that will be prepared under GAAP for the first time in a complete version for the financial year 2009-2010: the Government's aim in making the commitment to WGA is to provide improved data for fiscal planning, to increase transparency and to improve accountability to wards Parliament (Chow et al., 2007).

\subsection{European Union (European Commission)}

EU is a supranational PA, result of a complex and long cooperation process and voluntary peaceful integration, unique and still on going, that some European countries have started from the " 50 s of the last century.

This PA's supranational nature influences its institutional organizational and working mechanisms, characterized by a relevant degree of complexity and heterogeneity; it is a public organization much younger than national States, hardly 


\section{Public sector financial reforms: which convergence between European member states?}

comparable to them from a political and institutional point of view, also because of different developed functions (Pollit \& Bouckaert, 2004: 58-61).

During last decade many reform processes have begun, involving several EU dimensions (organization, management and control), both because of the institutional crisis occurred at the end of the '90s (Gozi, 2005) and the enlargement process: EU members increased from six to twenty-seven, and this fact made inappropriate the original model shaped by the European Communities' founding fathers.

Within the EU complex framework, the attention will be focused on the European Commission (EC), a European institution ${ }^{\text {xi }}$ with executive powers to ensure the proper implementation of European legislation, budget and communitarian programs. Then, in relation to the EU accounting model, it plays a role of utmost importance, defining accounting principles and rules to be applied by other EU institutions and having the task of consolidating the various EU bodies' accounts.

The EC reform process started in 2000 with the white book publication (European Commission, 2000): the reform program is based on the principles of accountability, efficiency and effectiveness of actions put in place and transparency within the Commission, as well as towards external actors (Levy, 2004). Intervention areas envisaged by the reform are essentially three: the implementation of an activity-based management system (also for the budgeting process); the reassessment of human resources policies and management; the reform of financial management, control and audit systems (European Commission, 2000).

Within the third above mentioned intervention area, the EC accounting modernization project - called ABAC, accrual based accounting - finds its place: it concerns accounting systems and financial reporting, as well as EU consolidated financial statements. Begun in 2002 (European Commission, 2002) ${ }^{\mathrm{xi}}$, it is not fully completed yet, but it achieved one of its most important steps in the preparation of the annual accounts 2005, only based on accrual accounting bookkeeping. Main tools used to realize $\mathrm{ABAC}$ reform are Financial Regulation and Implementing Rules.

EC chose to introduce accrual accounting basing on IPSAS (Gray, 2006): "adopting accounting rules and methods, the Commission's accounting officer shall be guided by the internationally accepted accounting standards for the public sector, but may depart from them where justified by the specific nature of the Communities"” (art. 133, par. 2, Financial Regulation).

Current accounting system is a dual system: accrual accounting has been implemented without leaving from cash accounting, used to manage budget 
appropriations. In particular, as far as the budgetary accounting is concerned, expenses are recorded under a modified cash basis, revenues under a cash basis; with regard to financial accounting, it is accrual based and realized with doubleentry bookkeeping. The coexistence of the two accounting systems is possible thanks to concerning software's integration (European Commission, 2007 and 2008).

On the basis of what the Financial Regulation states (art. 124), financial statements are drawn up in accordance with generally accepted accounting principles, that are going-concern basis, prudence, consistent accounting methods, comparability of information, materiality, no netting, reality over appearance, accrual-based accounting. Implementing Rules provide an interpretation of these principles with reference to EU's peculiar features and activities (art. 186-192).

Then, the EC Accounting Officer, helped by an Accounting Standards Committee, has issued fifteen accounting rules: Committee's role is to deliver an independent professional judgement on the accounting standards and rules proposed by the Commission's Accounting Officer and to advice him on financial reporting principles and standards' application (Introduction of Accounting Rules, par. II.5).

Through these accounting rules - regarding main financial statements' items, their measurement rules and disclosure requirements - EC has taken into account communitarian activities and peculiarities and has:

- identified which IPSAS can be directly applied, without integration need;

- detailed and adapted some IPSAS;

- created some "new" standards regarding areas left uncovered by IPSAS xiii.

Every standard is divided into paragraphs: in addition to an introductory section regarding general purposes of the accounting rule, key-words, measurement rules and disclosure requirements are listed; last part is the reference rules section, in which IPSAS (also the ones that cannot be applied, with specific motivations), IAS/IFRS (completing or substituting IPSAS, if they lack) and financial regulation articles which the document refers are listed.

EU financial reporting includes several documents and annexes. All European institutions and bodies have to draw up financial statements based on the above mentioned accounting rules, in addition to budget accounts.

In the balance sheet, drawn up as a list, both assets and liabilities are divided between current and not current: their algebraic sum allows determining net assets. This item includes, in addition to the economic outturn of the year (surplus or deficit), some reserves - also the fair value application one - and the amounts to be called from member States ${ }^{\text {xiv }}$. 
Public sector financial reforms: which convergence between European member states?

The economic outturn account, also drawn up as a list, contains operating revenues and expenses: the first ones are divided into own resource and contribution revenues and other operating revenues, the second ones into administrative expenses and operating expenses. Then, the economic outturn of the year is calculated adding up the surplus from operative activities, financial revenues and expenses, movements in employee benefits liability and share of net surplus (deficit) of associates and joint ventures.

While there are not peculiarities concerning the statement of changes in net assets - in line with IPSAS' requirements - with reference to cashflow table EC employs the indirect method, despite IPSASB recommends the direct method application. Operations are grouped into three areas: operating activities, increases/decreases in employee benefits liabilities and investing activities.

Then, the notes to the financial statements provide analytical and integrative information about accounting items content in the above mentioned statements, included additional information prescribed by internationally accepted accounting practice, where such information is relevant to the EC activities (Financial Regulation, par. 126.2).

While each EU institution and body has to draw up financial statements composed as described above, EC has to arrange also EU consolidated financial statements.

\subsection{Comparative analysis}

Coherently to the research aim, the analysis of three European countries and the EC has been realized. Even if the attention has been focused on accounting subjects, at the beginning we wanted to concentrate on some institutional and administrative system's features that influence public management reform processes, thus also the ones concerning financial public management.

\section{Table 1. Institutional features}

\begin{tabular}{|c|c|c|c|}
\hline & France & Italy & 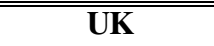 \\
\hline State structure & un itary State & unitary State & unitary S tate \\
\hline $\begin{array}{l}\text { Constitution } \\
\text { (form } \\
\text { of government) }\end{array}$ & $\begin{array}{l}\text { semi-presidential } \\
\text { republic }\end{array}$ & parliamentary republic & $\begin{array}{l}\text { constitutional } \\
\text { monarchy }\end{array}$ \\
\hline Political system & $\begin{array}{c}\text { intermediate: } \\
\text { majoritarian features } \\
\text { with a multiparty system }\end{array}$ & $\begin{array}{c}\text { imperfect majoritarian: } \\
\text { two main coalitions of } \\
\text { political parties }\end{array}$ & $\begin{array}{c}\text { majoritarian: } \\
\text { two major } \\
\text { political parties }\end{array}$ \\
\hline Legal system & civil law & civil law & common law \\
\hline $\begin{array}{l}\text { Administrative } \\
\text { system/culture }\end{array}$ & $\begin{array}{l}\text { predominantly } \\
\text { rechtsstaat }\end{array}$ & rechtsstaat & public interest \\
\hline
\end{tabular}

Vol. 8, No.4 


\begin{tabular}{|l|c|c|c||}
\hline $\begin{array}{l}\text { Public sector } \\
\text { structure }\end{array}$ & $\begin{array}{c}\text { increasingly } \\
\text { decentralized (after } \\
\text { decentralization re forms } \\
\text { started in the '80s) }\end{array}$ & $\begin{array}{c}\text { increasingly } \\
\text { decentralized } \\
\text { (constitutional reform } \\
\text { in 2001) }\end{array}$ & centralized \\
\hline
\end{tabular}

Table 1 does not intentionally include EU/EC, because we did not consider relevant comparing institutional elements of nations with a supranational PA. The table underlines that, apart from the unitary State common feature, there are much more similarities between France and Italy, like several studies show. However, those similarities do not reflect on performed accounting reform processes, as we are going to point out.

Referring to the financial management reform processes, we paid particular attention to accounting system and financial reporting reforms realised in recent years.

Except in the UK, those reforms are more or less contemporaries: table 2 shows the formal beginning year, even if changing processes often had more far origins. The early begun accounting reform process is that one of the UK and this confirms the Anglo-Saxon origin of NPM and NPFM processes (Likierman et al., 1995), even if a complete application can be considered working only at the beginning of the XXI century.

Compared to their objectives, in terms of «minimum results» they can be considered achieved, even if in some cases few aspects have to be improved: for instance, as for EC, not all decentralized agencies have migrated to ABAC system, as well as European Developed Fund accounts ${ }^{\mathrm{xV}}$.

Civil law countries' processes, included EU - whose administrative system is influenced by French administrative culture for historical reasons - started with law and rules, whereas the UK favoured technical nature documents.

One of the most important elements appearing from the carried out analysis is the introduction of accrual accounting, according to international trends, even if it has been made in different times, ways and intensity.

This is true in France, UK and EC, whereas in Italy there is a different situation. Actually, while in the other countries government accounts quality improvement has been carried out through the introduction of an accrual based financial reporting, in Italy a cost accounting system has been realized, that is not linked with financial accounting ${ }^{\text {xvi }}$. For this reason, Italian accounting system has been submitted to some criticisms. It is only dedicated to costs measurement, completely ignoring the revenues evolution, not deriving from a double-entry bookkeeping, but from a cash accounting system (single-entry method): this can be the source of data 


\section{Public sector financial reforms: which convergence between European member states?}

lacks and low reliability (Pavan \& Reginato, 2005: 72). Also in France accrual based information derives from budgetary accounting, but it is different, because this process feeds and is adapted to financial statements' drawing up.

Table 2. Accounting and financial reporting reform processes

\begin{tabular}{|c|c|c|c|c|}
\hline & France & Italy & UK & EC \\
\hline Objective & $\begin{array}{l}\text { financial } \\
\text { reporting } \\
\text { based } \\
\text { on accrual } \\
\text { accounting } \\
\end{array}$ & $\begin{array}{c}\text { cost accounting } \\
\text { to s upport } \\
\text { budgeting process }\end{array}$ & $\begin{array}{c}\text { financ ial reporting } \\
\text { bas ed on accrual } \\
\text { accounting } \\
\text { (RAB reform) }\end{array}$ & $\begin{array}{c}\text { financial reporting } \\
\text { based on acc rual } \\
\text { accounting } \\
\text { (ABAC reform) }\end{array}$ \\
\hline Start & 2001 & 2000 & $1993^{x v i i}$ & 2000 \\
\hline $\begin{array}{l}\text { Present } \\
\text { situation }\end{array}$ & completed & completed & completed & completed \\
\hline Tools & 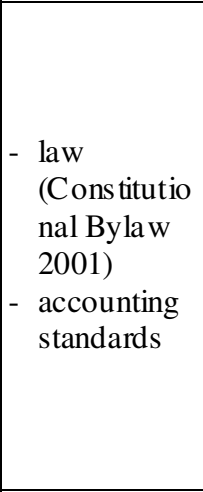 & $\begin{array}{l}\text { - law (L. 94/1997, } \\
\text { D. Lgs. } \\
\text { 279/1997 and } \\
\text { other ministerial } \\
\text { rules) }\end{array}$ & \begin{tabular}{|l} 
- \\
green paper \\
- 1994$)$ \\
white paper \\
(1995) \\
- Government \\
Resources and \\
Accounts Act \\
(2000) \\
- Government \\
Financial \\
Reporting \\
Manual (yearly \\
updated)
\end{tabular} & 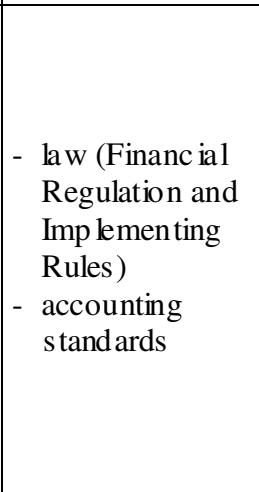 \\
\hline Actors & 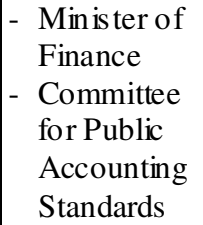 & $\begin{array}{l}\text { - } \text { Min is ter of } \\
\text { Economy and } \\
\text { Finance } \\
\text { - State General } \\
\text { Accounting } \\
\text { Department }\end{array}$ & $\begin{array}{l}\text { - Her Majesty's } \\
\text { Treasury } \\
\text { - Financial } \\
\text { Reporting } \\
\text { Advisory Board }\end{array}$ & $\begin{array}{l}\text { - EC DG Budget } \\
\text { - Accounting } \\
\text { Standards } \\
\text { Committee }\end{array}$ \\
\hline
\end{tabular}

Great similarity of budgetary accounting between France and EC has come out: revenues are recorded only under cash basis, instead of expenses, that are recorded under modified cash basis. Even if budget was not considered in this paper, we underline that the UK is the only country with an accrual budget among the analysed cases.

The dual system choice is another element that defines accounting reforms: it is characterised by cash accounting maintenance together with accrual accounting. This is probably due both to a more gradual introduction of these accounting changes - for costs' transition project and for historical tradition and habits of 
administrative staff in dealing with cash accounting (IFAC-PSC, 2003b) - and to peculiarities of carried out central government and EC activities, mostly made of fund transactions.

\section{Table 3. Basis of the accounting systems}

\begin{tabular}{||l|c|c|c|c||}
\hline & France & Italy & UK & EC \\
\hline $\begin{array}{l}\text { Cash } \\
\text { accounting }\end{array}$ & $\begin{array}{c}\mathrm{X} \\
\text { (revenues) }\end{array}$ & $\mathrm{X}$ & $\mathrm{X}$ & $\begin{array}{c}\mathrm{X} \\
\text { (revenues) }\end{array}$ \\
\hline $\begin{array}{l}\text { Modified cash } \\
\text { accounting } \\
\text { Accrual } \\
\text { accounting }\end{array}$ & $\begin{array}{c}\mathrm{X} \\
\text { (expenses) } \\
\mathrm{X}\end{array}$ & $\mathrm{X}$ & - & $\mathrm{X}$ \\
(expenses)
\end{tabular}

Accounting principles play an important role among tools used to carry out accounting reform processes. Table 4 and 5 sum up and compare the analysed cases: excluding Italy for the above mentioned reasons, some meeting points can be noticed.

As for general accounting principles, they do not coincide perfectly, but there are many analogies: while France and EC make a list of them, the UK does not make this list, referring directly to the IASB's framework and only suggesting integrations and interpretations with reference to public sector's features and activities. Actually, both the UK (indirectly) and France and EC (directly) refer to main assumptions on which both the IASB model and that one of IPSAS are based, that is going concern, accrual accounting and consistency, as well as to some of the assumptions of secondary importance.

\section{Table 4. Accounting principles}

\begin{tabular}{|c|c|c|c|c|}
\hline & France & Italy & 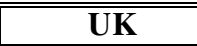 & $\overline{\mathrm{ECC}}$ \\
\hline 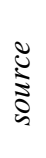 & Conceptual Framework & --- & $\begin{array}{c}\text { Government } \\
\text { Financial } \\
\text { Reporting } \\
\text { Manual }\end{array}$ & $\begin{array}{l}\text { Financial Regulation and } \\
\text { Implementing Rules }\end{array}$ \\
\hline & $\begin{array}{l}\text { - compliance } \\
\text { - faithful repres entation } \\
\text { - true and fair view } \\
\text { - accrual basis } \\
\text { - going concern bas is } \\
\text { - cons is tency of methods } \\
\text { - information quality: }\end{array}$ & --- & $\begin{array}{l}\text {-true and fair } \\
\text { view } \\
\text {-reference to } \\
\text { IASB's } \\
\text { framework } \\
\text { accounting } \\
\text { principles }\end{array}$ & $\begin{array}{l}\text { - going concern basis } \\
\text { - prudence } \\
\text { - consistent accounting } \\
\text { methods } \\
\text { - comparability } \\
\text { of information } \\
\text { - materiality }\end{array}$ \\
\hline
\end{tabular}


Public sector financial reforms: which convergence between European member states?

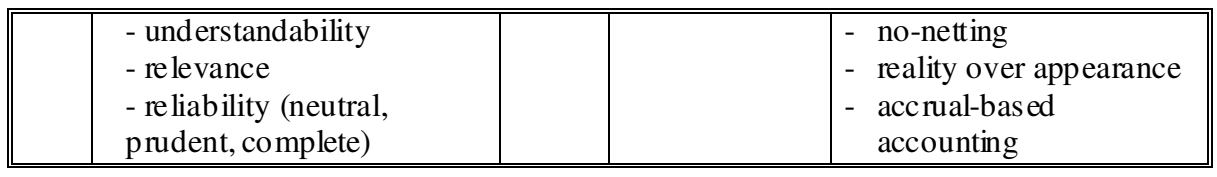

The list drawn up by French Conceptual Framework is open: "the list of principles is not necessarily exhau stive. It covers the principles that seem to be common to all of the business accounting standards. The fact that a principle is not mentioned does not mean that it is not deemed to apply to the central government" (Conceptual Framework, par. III.1).

As far as accounting standards are concerned, the UK government refers to GAAP, in which it includes IASB's pronouncements and no more those ones issued by the national standard setter (the Accounting Standards Board). The UK is carrying out the convergence project through IAS/IFRS in current financial year (as other countries has already done, such as New Zealand), using the Government FRM only to provide integrations and interpretations of GAAP with particular reference to public sector.

Table 5. Financial reporting accounting standards

\begin{tabular}{|c|c|c|c|}
\hline France & Italy & $\overline{\text { UK }}$ & $\overline{E C}$ \\
\hline $\begin{array}{l}\text { Central Government } \\
\text { Accounting Standards }\end{array}$ & --- & $\begin{array}{c}\text { General Accepted } \\
\text { Accounting Practice }\end{array}$ & Accounting Rules \\
\hline $\begin{array}{l}\text { Conceptual framework for } \\
\text { c entral government } \\
\text { accounting }\end{array}$ & \multirow{12}{*}{---} & \multirow{12}{*}{$\begin{array}{l}\text { - Companies Act } \\
2006 \\
\text { - IASB } \\
\text { pronouncements } \\
\text { - accumulated } \\
\text { accounting } \\
\text { knowledge }\end{array}$} & Introduction \\
\hline 1. Financial s tatements & & & 1. Group accounting \\
\hline 2. Expenses & & & 2. Financial statements \\
\hline 3. Sovereign revenues & & & 3. Expenses and payables \\
\hline $\begin{array}{l}\text { 4. Operating revenues, } \\
\text { intervention revenues } \\
\text { and financial revenues }\end{array}$ & & & 4. Revenues and receivables \\
\hline 5. Intangible as sets & & & 5. Pre-financing \\
\hline 6. Tangible assets & & & 6. Intang ib le fixed assets \\
\hline 7. Financial ass ets & & & 7. Tangible fixed assets \\
\hline 8. Inventories & & & 8. Leases \\
\hline $\begin{array}{l}\text { 9. Claims related to current } \\
\text { assets }\end{array}$ & & & 9. Stock \\
\hline $\begin{array}{l}\text { 10. Central government } \\
\text { cash pos ition components }\end{array}$ & & & $\begin{array}{l}\text { 10. Provis ions, contingent } \\
\text { assets and liabilities }\end{array}$ \\
\hline $\begin{array}{l}\text { 11. Financial debts and } \\
\text { derivate financial } \\
\text { instruments }\end{array}$ & & & $\begin{array}{l}\text { 11. Financial ass ets and } \\
\text { liabilities }\end{array}$ \\
\hline
\end{tabular}

Vol. 8, No.4 


\begin{tabular}{|c|c|c|c|}
\hline France & Italy & $\overline{\text { UK }}$ & EC \\
\hline $\begin{array}{l}\text { Central Government } \\
\text { Accounting Standards }\end{array}$ & -- & $\begin{array}{c}\text { General Accepted } \\
\text { Accounting Practice }\end{array}$ & Accounting Rules \\
\hline $\begin{array}{l}\text { 12. Provisions for ris ks and } \\
\text { liabilities, non-financial } \\
\text { liabilities and other } \\
\text { liabilities }\end{array}$ & & & 12. Employee benefits \\
\hline $\begin{array}{l}\text { 13. Commitments to be } \\
\text { disclosed in notes to the } \\
\text { financial statements }\end{array}$ & & & $\begin{array}{l}\text { 13. Foreign currency } \\
\text { translation }\end{array}$ \\
\hline $\begin{array}{l}\text { 14. Accounting policies, } \\
\text { changes in accounting } \\
\text { estimates and errors }\end{array}$ & & & $\begin{array}{l}\text { 14. Economic result of the } \\
\text { year, errors and changes } \\
\text { in accounting polic ies }\end{array}$ \\
\hline $\begin{array}{l}\text { 15. Events after the } \\
\text { reporting date }\end{array}$ & & & 15. Related party disclos ure \\
\hline
\end{tabular}

On the other hand, France and EC chose to issue accounting standards especially dedicated to government financial reporting. In both cases, it is evident that those standards have IPSAS as the main reference point, even if EC position seems stronger: while France points out French Chart of Accounts as the first reference point, EC directly recognises IPS AS' authority, as settled by Financial Regulation.

Thus, a substantial convergence situation seems to appear, if we consider that IPSAS are developed adapting IAS/IFRS to public context, where it is possible ${ }^{\text {xviii }}$, apart from some specific PAs' aspects that have not comparison in profit-oriented companies (for instance IPSAS 22, 23 and 24). Then, IPSAS explicitly refer to IAS/IFRS framework, given that IPSASB has not issued a specific framework yet.

With reference to financial reporting, some convergence elements also stand up: omitting Italian peculiar situation, France, the UK and EC draw up the balance sheet, the statement of financial performance, the statement of cash flow and concerning notes, while the statement of changes in equity and the whole of government accounts are drawn up only by the UK and EC.

Of course, statements are not the same, neither in structure nor in denomination, becau se of freedom that IAS/IFRS and IPSAS let in this field. While with reference to balance sheet statements are rather similar, the statement of financial performance has got much more distinctions: the UK and EC documents are rather brief and they show the operating surplus/deficit; French document is more detailed, because it is divided into three parts and gives evidence of net operating expenses, net intervention expenses (making a distinction based on government activity/function, if it concerns service delivering or fund transfer) and net financial expenses. 


\section{Public sector financial reforms: which convergence between European member states?}

However, in some cases contact points are only formal, referred to representation in the statements. In fact, there are several unresolved questions: different countries adopted different behaviour lines concerning them, such as measurement rules for assets (for instance heritage assets, military assets and infrastructure assets) and provisions (including those ones arising from employee benefits), that are some of the most important critical aspects closely related to government activities' peculiarities. Those problems are very relevant, because they directly influence valuation and presentation of public assets and liabilities, in their wider meaning (as to intergenerational equity also).

\section{Table 6. F inancial statements}

\begin{tabular}{|c|c|c|c||}
\hline France & Italy & UK & EC \\
\hline $\begin{array}{c}\text { statement of financial } \\
\text { position }\end{array}$ & balance sheet & $\begin{array}{c}\text { statement of financial } \\
\text { pos ition }\end{array}$ & balance sheet \\
\hline $\begin{array}{c}\text { sumplus/deficit } \\
\text { statement }\end{array}$ & operating cost statement & $\begin{array}{c}\text { economic outturn } \\
\text { account }\end{array}$ \\
\hline statement of cash flow & statement of cashflow & cashflow table \\
\hline $\begin{array}{c}\text { notes to the financial } \\
\text { statements }\end{array}$ & $\begin{array}{c}\text { statement of changes in } \\
\text { equity }\end{array}$ & $\begin{array}{c}\text { statement of changes } \\
\text { in net ass ets/liabilities }\end{array}$ \\
\hline & & $\begin{array}{c}\text { notes to the annual } \\
\text { accounts }\end{array}$ & $\begin{array}{c}\text { notes to the financ ial } \\
\text { statements }\end{array}$ \\
\hline & $\begin{array}{c}\text { whole of government } \\
\text { accounts }\end{array}$ & $\begin{array}{c}\text { EU consolid ated } \\
\text { financ ial statements }\end{array}$ \\
\hline
\end{tabular}

Referring to national government, the UK is the only one that provides a whole of government accounts. As for EC, it is continuing to widen the number of EU entities included in consolidated financial statements and to improve accounting data homogeneity, thanks to the progressive introduction of the EC ABAC system in decentralized bodies (European Commission, 2007).

\section{DISCUSSION AND CONCLUSIONS}

Nowadays, business accounting models are the object of a progressive harmonization process: internationalization and integration of real and financial markets imply an increasing information need for economic operators for an aware support choices adoption. Therefore, the employed accounting language has to be more and more clear and understandable to the most of any stakeholders' companies. This demand has been taken in by EU, which imposed IAS/IFRS compulsory adoption to all listed companies. But what is going on about PAs?

With reference to the research questions, according to the documental analysis, the following comments can be made.

Vol. 8, No. 4 
Accrual accounting seems more and more widespread, even if it has been made in different times, ways and intensity. The accounting system and the financial reporting choices made within the analyzed reforms seem to be in harmony with international trends, with the exception of Italy. It is in a rather difficult situation, because its accounting system is mainly devoted to monitor budget execution; it does not provide data for the presentation of the government financial position and performance, so it should have to improve its accounts quality, as other European governments are trying to do.

As for the convergence between the selected cases' accounting models, at a formal level some analogies came out, but there are many differences at a substantial level: diverging measurement rules adopted - rather than differences in technical vocabulary - arising from different accounting standards and different reform process fulfilment phases also, as they need long times. Full accrual accounting application is very expensive for wide and complex PAs as central governments are, referring above all to their capital assets: their complete recognition and valuation imply long time.

An influence of EU on the accounting reforms carried out by the analyzed European member States does not seem identifiable: in the UK, for example, it started earlier and developed in a different way compared to the EC. Many similarities between EC and France appear, in addition to contemporary accounting reforming processes: this is probably due to the administrative culture's similarity, deriving from historical reasons.

This study - whose main limit is that it only concerns three countries, really few to generalise the research results - points out that, referring to the analysed cases, it seems that it is not possible to talk about a relevant European government accounting and financial reporting harmonization process. About this topic EC could play an important role in the future, taking decisions similar to those ones assumed for listed companies, even if a communitarian intervention in this field could clash with the EU member States' national autonomy, with reference to their budgets and accounting models (Jones, 2007: 103).

IPSAS do not still have the same importance than IFRS, given that the adoption of these accounting standards is not compulsory for European PAs. However, their influence authority seems to be confirmed by their adoption by the EC, that, with its Financial Regulation, indirectly supports the IPSAS' use by the EU member States' PAs ${ }^{\mathrm{xix}}$.

Concluding, an encouragement to public accounting systems and financial reporting harmonization seems to acquire more and more importance, for different reasons. 


\section{Public sector financial reforms: which convergence between European member states?}

Firstly, to realize consolidation of PAs expenditures and achieved results at European level, also in consideration of the obligations coming from the membership of different national States to EU. Referring to this last aspect, the need of promoting a convergence between national accounting (ESA 95 system) and government accounting has been pointed out in many circumstances (Jones, 2003; IFAC-IPSASB, 2005). Lüder argues "a shift of governmental accounting bases towards accrual as well as a transnational standardisation of procedures and practices" (Lüder, 2000: 127) in order to carry out this progressive convergence - considering the ESA 95 features - also with the aim of an impro vement of cross-country comparisons.

Then, accounting harmonization searching is important for performances comparisons among different PAs, operating in various countries, in order to increase transparency for all stakeholders, improving accountability in its different kinds (Pavan \& Reginato, 2005).

Moreover, simplification aims in public sector financial reporting should have achieved in searching a greater harmonization: "it is not enough to keep the books accurately; the books have to be open to the public. When the public does not have the time or ability to inspect the accounts, governments have to make the task easier by preparing comprehensible - as well as comprehensive - financial statements" (Chan, 2003: 18).

A minimal technical vocabulary sharing would be desirable, allowing a greater linguistic homogeneity: as for financial reporting, we noticed that some documents have different names, even if they are very similar in their structure, and this is a barrier for European PAs accounting harmonization. Even if we do not have to forget that different words employ comes from diverging accounting concepts: "this diversity is much more than a matter of mere vocabulary: at bottom, there are often polarised ways of thinking about accounting systems, with what can be termed an Anglo-American view of accounting at one extreme and a continental European view at the other" (Jones, 2007: 91).

However, open problems remain: they outline ideas and suggestions for further research.

As mentioned above, the analysed cases confirm that the international trend of government accounting is moving to accrual accounting. Nevertheless, is there a real need of accrual accounting in PAs? If yes, is it true for all public sector level (central, local, supranational) and in all fields (health, education, etc.)?

Actually, there are many theoretical and empirical studies - as the paper's second section shows - that do not support a full accrual accounting implementation in the whole public sector. Christiaens and Rommel, for example, suggest accrual 
accounting use "when government engages in businesslike activities", while cash accounting should be applied when PAs "provide social services without business like or profit objectives", hoping a combination of the two systems when different kinds of activities coexist (Christiaens \& Rommel, 2008: 59-75).

In particular, problems arise from some PAs' peculiarities, such as market absence: this causes some relevant consequences concerning definition, valuation, classification, depreciation and presentation of capital assets (Christiaens, 2004: 766).

Moreover, it is important to point out that a single kind of accrual accounting does not exist: full cash accounting and full accrual accounting may be considered as two limit points of a wide range of different alternatives, being hybrid solutions (IFAC-PSC, 2000: 15; Blöndal, 2002: 44).

Finally, real usefulness of accrual accounting reports - concerning their influence on improvement of politicians and other stakeholders' decision processes - seems to be not proved: it is not sure that public sector decision makers will find such information useful, relevant, and understandable (Jones \& Pendlebury, 2004; Steccolini, 2004b, Brusca \& Montesinos, 2006).

Thus, it is not still clear what is the best path towards European government accounting and financial reporting harmonization.

\section{REFERENCES}

Anessi Pessina, E. (2007) L'evoluzione dei sistemi contabili pubblici. Aspetti critici nella prospettiva aziendale, Milano: Egea

Anselmi, L. (ed.) (2006) Modelli economico-patrimoniali per il bilancio e la contabilità di Stato, Milano: Giuffrè

Antony, R.N. (2000) „,The fatal defect in the federal accounting system”, Public Budgeting \& Finance, vol. 20, no. 4: 1-10

Aucoin, P. (1990) „Administrative reform in public management: paradigms, principles, paradoxes and pendulums", Governance, vol. 3, no. 2: 115-137

Barzelay, M. (2001) The New Public Management. Improving research and policy dialogue, Berkeley: University of California Press

Berry, A.J. \& Otley, D.T. (2004) „Case-based research in accounting”, in Humphrey, C. and Lee, B. (eds.) The real life guide to accounting research. A behind-the-scenes view of using qualitative research methods, Amsterdam: Elsevier

Blöndal, J.R. (2002) „Accrual accounting and budgeting: key issues and recent developments", OECD Journal on Budgeting, vol. 3, no. 1: 43-59

Brorström, B. (1998) „Accrual accounting, politics and politicians”, Financial Accountability \& Management, vol. 14, no. 4: 319-333 


\section{Public sector financial reforms: which convergence between European member states?}

Brusca, I. \& Montesinos, V. (2006) „Are citizens significant users of government financial information?", Public Money \& Management, vol. 26, no. 4: 205-209

Caperchione, E. (1999) „Caratteri di uniformità nelle riforme dei sistemi di contabilità pubblica di alcuni Paesi europei ed extra-europei”, Azienda Pubblica, vol. 12, no. 5:559-581

Chan, J.L. (1994) „Accounting and financial management reform in the United States Government: an application of professor Lüder's contingency model", in Buschor, E. and Schedler, E. (eds.) Perspectives on performance measu rement and public sector accounting, Bern: Haupt

Chan, J.L. (2003) „Government accounting: an assessment of theory, purposes and standards", Public Money \& Management, vol. 23, no. 1: 13-20

Chan, J.L. \& Jones, R.H. (eds.) (1988) Governmental accounting and auditing: international comparisons, London: Routledge

Chevauchez, B. (2002) „Government budgeting and accounting reforms in France", in Models of public budgeting and accounting reforms, OECD: Paris

Chow, D.S.L., Humphrey, C.G. and Miller, P.B. (2005) „Financial management in the UK public sector: historical development, current issues and controversies", in Guthrie, J., Humprhrey, C., Jones, L.R. and Oslon, O. (eds.) International Public Financial Management Reform. Progress, contradictions and challeng es, Greenwich: Information Age Publishing

Chow, D.S.L., Humphrey, C. \& Moll, J. (2007) „Developing whole of government accounting in the UK: grand claims, practical complexities and suggested future research agenda", Financial Accountability \& Management, vol. 23, no. $1: 27-54$

Christiaens, J. (2004) „Capital assets in governmental accounting reforms: comparing Flemish technical issues with international standards", European Accounting Review, vol. 13, no. 4: 743-770

Christiaens, J. \& Rommel, J. (2008) „Accrual accounting reforms: only for businesslike (parts of) governments", Financial Accountability \& Management, vol. 24, no. 1:59-75

Cole, A. \& Jones, G. (2005) „Reshaping the State: administrative reform and New Public Management in France", Governance, vol. 18, no. 4: 567-588

Edwards, J.R., Coombs, H.M. \& Greener, H.T. (2002) „British central government and 'the mercantile system of double entry' bookkeeping: a study of ideological conflict", Accounting, Organizations \& Society, vol. 27, no. 7: 637-658

Eisanhardt, K.M. (1989) „Building theories from case study research”, Academy of Management Review, vol. 16, no. 3: 532-550

Ellwood, S. (2003) „Bridging the GAAP across the UK public sector”, Accounting and Business Research, vol. 33, no. 2: 105-121

European Commission (2000) Reforming the Commission. A white paper. Part I and II, COM (2000) 200, European Commission: Brussels 
European Commission (2002) Modernisation of the accounting system of the European Communities, COM (2002) 755, Eu ropean Commission: Brussels

European Commission (2007) Progress report as at 31 March 2007 on the modernisation of the accounting system of the European Commission, COM (2007) 343, European Commission: Brussels

European Commission (2008) Modernising the EU accounts. Enhanced management information and greater transparency, Luxembourg: Publication Office

Fattore, G. (2005) Metodi di ricerca in Economia aziendale, Milano: Egea

FEE (2007) Accrual accounting in the Public Sector, Fédération des Experts Comptables Européens: Bru ssels

Ferlie, E., Pettigrew, A., Ashburner, L. \& Fitzgerald, L. (1996) The New Public Management in action, Oxford: Oxford University Press

Gozi, S. (2005) La Commissione europea: processi decisionali e poteri esecutivi, Bologna: Il Mulino

Gray, B. (2006) „Accounting standards and accrual accounting: the new challenges of the financial reporting system of the European Commission", in Zambon, S. (ed.) I principi contabili per le amministrazioni pubbliche, Milano: Franco Angeli

Gruening, G. (2001) „Origin and theoretical basis of New Public Management”, International Public Manag ement Journal, vol. 4, no. 1: 1-25

Guthrie, J. (1998) „Application of accrual accounting in the Australian public sector: rhetoric or reality?", Financial Accountability \& Management, vol. 14, no. 1: $1-19$

Guthrie, J., Oslon, O. \& Humprhrey, C. (1999) „Debating developments in New Public Financial Management: the limits of global theorizing and some new ways forward", Financial Accountability \& Management, vol. 15, no. 3/4: 209-228

Heald, D. (2005) „The implementation of resource accounting in UK central government", Financial Accountability \& Management, vol. 21, no. 2: 163-190

Her Majesty's Treasury (2001) Managing resources. Full implementation of Resource Accounting and Budgeting, Her Majesty's Treasury: London

Hodges, R. \& Mellett, H. (2003) „Reporting public sector financial results”, Public Management Review, vol. 5, no. 1: 99-113

Hood, C. (1991) „A public management for all seasons”, Public Administration, vol. 69 , no. 1: 3-19

Hood, C. (1995) „The New Public Management in the 1980s: variations on a theme", Accounting, Organization \& Society, vol. 20, no. 2/3: 93-109

IFAC-IPSASB (2005) International Public Sector Accounting Standards (IPSASs) and statistical bases of financial reporting: an analysis of differences and recommendations for converg ence, series Research report, New York: IFAC

IFAC-PSC (2000) Government financial reporting. Accounting issues and practices, series Studies, no. 11, New York: IFAC 


\section{Public sector financial reforms: which convergence between European member states?}

IFAC-PSC (2002) Resource accounting: framework of accounting standard setting in the UK central government sector, series Occasional papers, no. 5, New York: IFAC

IFAC-PSC (2003a) The modernization of government accounting in France: the current situation, the issues, the outlook, series Occasional papers, no. 6 , New York: IFAC

IFAC-PSC (2003b) Transition to the accrual basis of accounting: guidance for governments and government entities, second edition, series Studies, no. 14, New York: IFAC

Jones, L., Guthrie, J. \& Steane, P. (eds.) (2001) Learning from international public management reform, Oxford: Elsevier Science

Jones, L., Schedler, K. \& Mussari, R. (eds.) (2004) Strategies for public management reform, London: Elsevier

Jones, R.H. (2003) „Measuring and reporting the Nation's finances: statistics and accounting”, Public Money \& Management, vol. 23, no. 1: 21-27

Jones, R.H. (2007) „The function of government accounting in Europe", Polytechnical Studies Review, vol. 4, no. 7:89-110

Jones, R.H. \& Pendlebury, M. (1988) „Governmental accounting, auditing and financial reporting in the United Kingdom", in Chan, J.L. and Jones, R.H. (eds.) Governmental accounting and auditing: international comparisons, London: Routledge

Jones, R.H. \& Pendlebury, M. (2000) Public sector accounting, fifth edition, London: Prentice Hall

Jones, R.H. \& Pendlebury, M. (2004) „A theory of the published accounts of local authorities", Financial Accountability \& Management, vol. 20, no. 3: 305-325

Jurado-Sánchez, J. (2002) „Mechanisms for controlling expenditure in the Spanish Royal Household, c.1561-c.1808", Accounting, Business \& Financial History, vol. 12, no. 2: 157-185

Kettl, D.F. (2005) The global public management revolution, second edition, Washington: Brookings

Kickert, W.J.M. (2005) „Distinctiveness in the study of Public Management in Europe. A historical-institutional analysis of France, Germany and Italy", Public Management Review, vol. 7, no. 4: 537-563

Lapsley, I. \& Pallot, J. (2000) „Accounting, management and organizational change: a comparative study of local government", Management Accounting Research, vol. 11, no. 2: 213-229

Levy, R.P. (2004) „Between rhetoric and reality: implementing management reform in the European Commission", International Journal of Public Sector Management, vol. 17, no. 2: 166-177

Likierman, A., Heald, D., Georgiou, G. \& Wright, M. (1995) „Resource accounting and budgeting: rationale and background", Public Administration, vol. 73, no. 4: $561-570$ 
Longo, F. (2001) Federalismo e decentramento. Proposte economico-aziendali per le riforme, Milano: Egea

Lüder, K. (1992) „A contingency model of governmental accounting innovations in the political-administrative environment' in Chan, J.L. and Patton, J.M. (eds.) Research in governmental and nonprofit accounting, Greenwich: JAI Press

Lüder, K. (1994) „The contingency model reconsidered: experiences from Italy, Japan and Spain", in Buschor, E. and Schedler, K. (eds.) Perspectives on performance measurement and public sector accounting, Berne: Haupt

Lüder, K. (2000) „National accounting, governmental accounting and crosscountry comparisons of government financial condition", Financial Accountability \& Management, vol. 16, no. 2: 117-128

Lïder, K. (2002) „Research in comparative governmental accounting over the last decade. Achievements and problems", in Montesinos, V. and Vela, J.M. (eds.) Innovations in governmental accounting, Boston: Kluwer

Lüder, K. \& Jones, R. (eds.) (2003) Reforming governmental accounting and budgeting in Europe, Frankfurt: Fachverlag Moderne Wirtscharft

Ministère de l'Economie, des Finances et de l'Industrie (2008) Central government accounting standards, available on-line at www.performancepublique.gouvr.fr

Montesinos, V. (ed.) (2000) Study on the preparation and the presentation of the consolidated accounts of the European Union, Brussels: European Commission

Mussari, R. (1995) Italian local government accounting reform: an application of professor Lüder's contingency model, paper presented to the 5th CIGAR Conference, Paris

Mussari, R. (1999) La valutazione dei prog rammi nelle aziende pubbliche, Torino: Giappichelli

Mussari, R. (2005a) „Public Sector Financial Management Reform in Italy”, in Guthrie, J., Humprhrey, C., Jones, L.R. and Oslon, O. (eds.) International Public Financial Management Reform. Progress, contradictions and challenges, Greenwich: Information Age Publishing

Mussari, R. (ed.) (2005b) I sistemi di contabilità e bilancio dello Stato nell'Europa comunitaria, Padova: Cedam

Olson, O., Guthrie, J. \& Humphrey, C. (eds.) (1998) Global warning: debating international developments in New Public Financial Management, Bergen: Cappelen Akademisk Forlag

Olson, O., Humphrey, C. and Guthrie, J. (2001) „Caught in an evaluatory trap: a dilemma for pubic services under NPFM", European Accounting Review, vol. 10 , no. $3: 502-522$

Patton, M.Q. (2002) Qualitative research \& evaluation methods, third edition, Thousand Oaks: Sage

Pavan, A. \& Reginato, E. (2005) Prospettive di accountability ed efficienza nello Stato italiano, Milano: Giuffrè 


\section{Public sector financial reforms: which convergence between European member states?}

Pallot, J. (1997) „Infrastructure accounting for local authorities: technical management and political context", Financial Accountability \& Management, vol. 13, no. 3: 225-242.

Perrin, J. (1998) „From cash to accruals in 25 years”, Public Money \& Management, vol. 18, no. 2: 7-10

Pollitt, C. \& Bouckaert, G. (eds.) (2004) Public Management Reform. A Comparative Analysis, second edition, Oxford: Oxford University Press

Pollit, C., van Thiel, S. \& Homburg, V. (eds.) (2007) New Public Management in Europe. Adaptation and alternative, New York: Palgrave Macmillan

Ragioneria Generale dello Stato (2008) Principi e regole contabili del sistema di contabilità economica delle amministrazioni pubbliche, Ministero dell'Economia e delle Finanze: Roma

Standish, P.E.M. (1990) „Origins of the Plan Comptable Général: a study in cultural intrusion and reaction”, Accounting and Business Research, vol. 20, no. $80: 337-351$

Steccolini, I. (2004a) Accountability e sistemi informativi negli enti locali: dal rendiconto al bilancio sociale, Torino: Giappichelli

Steccolini, I. (2004b) „Is the annual report an accountability medium? An empirical investigation into Italian local governments", Financial Accountability \& Management, vol. 20, no. 3: 327-35049

Stewart, J. \& Walsh, K. (1994) „Performance management: when performance can never be finally defined", Public Money \& Management, vol. 14, no. 2: $45-49$

Van der Hoek, M.P. (2005) „From cash to accrual budgeting and accounting in the public sector: the Dutch experience", Public Budgeting \& Finance, vol. 25, no. $1: 32-45$

Vela, J.M. \& Fuertes, I. (2000) „Local government accounting in Europe: a comparative approach", in Caperchione, E. and Mussari, R. (eds.), Comparative issues in local government accounting, Boston: Kluwer

Yamamoto, K. (1999) „Accounting system reform in Japanese local governments”, Financial Accountability \& Management, vol. 15, no. 3/4: 291-307

Yin, R.K. (2003) Case study research: design and methods, third edition, Thousand Oaks: Sage

${ }^{\text {i }}$ Some researchers criticize the NPM's fe ature of paradigm (Gruening, 2001).

ii For all these documents, the version available at $15^{\text {th }}$ March 2009 has been used.

iii A Public Accounting Standards Interpretation Committee was created in 2004, because sometimes ac counting standards implementation needs an interpretation process, due to the fact that new items, unknown when the standard was adopted, can generate questions and implementation doubts.

iv Accounting standard I.1 points out that the State financial position cannot be compared to the shareholders' equity in a business, since there is no initial capital amount or anything equivalent to it.

$\mathrm{v}$ "Resource accounting is the application of accrual accounting to the accounts of central government departments and pension schemes. It focuses on resources consumed over an accounting period rather than just cash spent, and relates resources consumed to departmental objectives" (IFACPSC, 2002: 6). 
vi It is a technical and operative tool being an out-and-out guide to annual accounts drawing up for all government departments. It replaced the old Resource Accounting Manual and it is available on line (www.financial-reporting.gov.uk).

vii In the UK, financial year starts $1^{\text {ฐ }}$ April and ends $31^{\text {st }}$ March.

viii FRM 2008-2009 (par. 1.5.3) specified that «the UK does not apply IPSAS directly, although the requirements of IPSAS are considered as part of the review of the applicability of UK accounting standards in the public sector context».

ix For example, the content of going concern principle is specified with reference to different kinds of go vernment reporting entities (FRM 2009-2010, par. 2.2.15).

$x$ Government FRM states that flexibility provided in IAS 1 to select the order of presentation of line items on the statement of financial position and to present on a liquidity basis is withdrawn, to ensure consistency and comparability among public reporting entities.

xi EU institutional framework is very complex: in addition to institutions (the most important are the Europe an Parliament, the European Commission, the Council of the EU and the Europe an Court of Auditors), there are financial bodies, advisory bodies, interinstitutional bodies and decentralized bodies (agencies).

xii EU accounting model's rethinking path opened since 2000, with a study carried out by a group of scholars, who provided suggestions and ideas about redefining EU financial reporting (Montesinos, 2000).

xiii For instance, accounting rule 5 is dedic ated to pre-financing, one of the EC acti vity's peculiarities.

xiv Net assets resulting from EU consolidated financial statements 2007 has a negative amount, opposite to the positive economic outturn, due to specific peculiarities of EU activities, with reference to fund relations with members States: "This amount represents that part of the expenses already incurred by the Communities up to December 2007 that must be funded by future budgets. Many expenses are recognised under accrual accounting rules in the year $\mathrm{N}$ although they may be actually paid in year $\mathrm{N}+1$ and funded by using the budget of year $\mathrm{N}+1$. The inclusion in the accounts of the se liabilities coupled with the fact that the corresponding amounts are financed from future budgets, results in liabilities greatly exceeding assets at the year-end" (EU consolidated financial statements 2007, notes).

xv Also in the French case, where the opening balance sheet was made at $1^{\text {st }}$ January 2006 , some improvements in capital assets recognition will be realized in future years, thanks to specific software's solutions (French Annual Accounts, 2007: 39).

${ }^{x v i}$ Manage ment accounting systems also exist in other analysed countries, but they are not mentioned because the y are out of the paper's objectives.

xvii The year 1993 refers to the first indic ation that change was anticipated came in the Chancellor's November 1993 Budget speech. The Green Paper, which followed eight months later, announced that Resource Accounting was to be introduced and that there would be a six-month consultation period on the proposals for other aspects, including planning and control within government and the information presented to the Parliament (Likierman et al., 1995: 563).

xviii IPSAS are converged with IFRS issued by the IASB by adapting them to a public sector context when appropriate. In undertaking that process, the IPSASB attempts, wherever possible, to maintain the accounting tre atment and original te xt of the IFRS unless there is a significant public sector issue which warrants a departure (Preface to IPSASs, par. 18).

xix Agreement regarding IPSAS seems to increase because they have also been adopted by some supranational-international public organizations, such as OECD, NATO (which already have an IPSAS-based financial reporting) and the United Nations (that has begun to upgrade its accounting processes and is expected to produce an IPSAS-compliant financial reporting in 2010). 